\title{
KAJIAN PERBANDINGAN \\ HISTORIOGRAFI PENDIDIKAN DI AMERIKA SERIKAT, AUSTRALIA, DAN INDONESIA
}

\author{
Hieronymus Purwanta \\ Jurusan Sejarah, Universitas Sanata Dharma, Yogyakarta. \\ purwantah@gmail.com
}

\begin{abstract}
This article compares historiography of education in United States, Australia, and Indonesia. It aims to understand similarities and differences text book of history learning in high school in three countries. The comparative study focuses on two aspects in historiography of education, i.e. approach and discourse. The result of study shows that in three country use the narrative approach. In Indonesia, beside narrative, the writers of history text book also used structural approach and apply theories, concepts, and generalization from social sciences and humanities. In aspect of discourse, the historiography of education in United States and Australia placed their peoples as subject and main actor in history. In other side, historiography of education in Indonesia placed their peoples as object in any historical act had been done by foreigner.
\end{abstract}

Keywords: historiography, education, Indonesia, Australia, United States.

\begin{abstract}
ABSTRAK
Artikel ini bermaksud membandingkan historiografi pendidikan di Amerika Serikat, Australia dan Indonesia. Tujuannya adalah untuk memahami persamaan dan perbedaan buku teks pelajaran sejarah yang digunakan untuk siswa SMA di ketiga negara. Kajian komparatif difokuskan pada dua aspek utama dari historiografi pendidikan, yaitu pendekatan dan wacana. Hasil kajian menunjukkan bahwa historiografi pendidikan di ketiga negara menggunakan pendekatan naratif. Di Indonesia, selain naratif, penulis buku teks pelajaran sejarah juga menerapkan pendekatan struktural dengan menggunakan teori, konsep, generalisasi dari ilmu sosial dan humaniora. Dari perspektif wacana, historiografi pendidikan di Amerika Serikat dan Australia menempatkan masyarakatnya sebagai subjek atau pemeran utama dalam sejarah. Di pihak lain, historiografi pendidikan di Indonesia menempatkan masyarakatnya sebagai objek dari berbagai tindakan historis yang dilakukan bangsa asing.
\end{abstract}

Kata kunci: historiografi, pendidikan, Indonesia, Australia, Amerika Serikat.

\section{PENDAHULUAN}

Secara garis besar, lembaga pendidikan bertanggungjawab untuk menjaga dan mengembangkan pengetahuan yang tumbuh di dalam masyarakat. Pendidikan sejarah, yang di pendidikan menengah ke bawah dikenal sebagai mata pelajaran, merupakan bagian sentral dari kurikulum pendidikan. Sejajar dengan tugas lembaga pendidikan, mata pelajaran sejarah memiliki tugas un- tuk menjaga dan mengembangkan identitas kultural masyarakat. Dengan menggunakan konteks India, Kochhar (2008: 27-28) menjelaskan tujuan pembelajaran sejarah di sekolah sebagai berikut.

... Mengembangkan kesadaran diri: Sejarah perlu diajarkan untuk mengembangkan pemahaman tentang diri sendiri. Untuk mengetahui siapa diri kita sendiri, diperlukan per- 
Kajian Perbandingan Historiografi ... - H. Purwanta

spektif sejarah... Tanpa pendalaman terhadap faktor-faktor sejarah tersebut, orang akan gagal memahami identitasnya sendiri.

Tanpa sejarah, bangsa India tidak akan tahu apa artinya menjadi orang India. Para politikus pun tidak akan sungguh-sungguh memahami untuk apa mereka menjadi pegiat partai dan transformasi apa yang sedang dilakukan oleh partainya. Tanpa sejarah, anak-anak sekarang tidak akan tahu kegigihan perjuangan yang dilakukan oleh para pemimpin nasional untuk memperoleh kemerdekaan dan peran yang besar dari masing-masing tokoh pada zamannya dalam memperjuangkan kemerdekaan.

Dari kutipan di atas dapat diambil pemahaman generalitatif bahwa pelajaran sejarah bertanggungjawab untuk mengembangkan pemahaman tentang diri sendiri sebagai bagian dari masyarakat bangsa. Setelah memahami diri sendiri, pada tingkat selanjutnya pelajaran sejarah juga bertugas untuk mengembangkan kompetensi peserta didik untuk mencermati dan memilih arah hidup menuju masa depan.

Tidak jauh berbeda dengan Kochhar, Moreau (2004: 30-31) menjelaskan bahwa mata pelajaran sejarah sebagai sarana untuk mewariskan identitas nasional:

... schools as nationalizing institutions that would "render the mass of people more homogeneous and thereby fit them more easily for uniform and peaceable government." Americans might not yet be a unique people, but the right kind of teaching, particularly in history, could help to produce a national consciousness. Identification with the nation might then reinforce the republic's political foundation. Every "child in America should be acquainted with his own country," wrote Webster. "As soon as he opens his lips, he should rehearse the history of his own country; he should lisp the praise of liberty and of those illustrious heroes and statesmen who have wrought a revolution in her favor.

Dengan adanya kesadaran nasional tersebut, menurut Moreau, menjadikan masyarakat lebih mungkin memiliki keseragaman pandangan terhadap keberadaan negara. Oleh karena itu, dengan ekstrim dia menyatakan bahwa sejak anak mampu membuka mulut, dia harus mempelajari sejarah bangsanya.

Di Indonesia, kesadaran peran penting mata pelajaran sejarah bagi pembangunan bangsa (nation building) sudah lama muncul. Salah satu tonggak penting kesadaran itu adalah pada Seminar Sejarah Nasional Indonesia I yang dilaksanakan di Yogyakarta pada tahun 1957 adalah sebagai berikut.

In a landmark First National Seminar in 1957, the tension between methodologically sound, "scientific" history and its ideologically-informed nationalist counterparts came to the fore. Asked to speak on the philosophy that ought to inform history writing, Soedjatmoko and Yamin took clearly opposing sides. The former warned forcefully against the danger of allowing history to be used to promote nationalist projects and pushed for strict adherence to standard historical methodology. Yamin asserted in equally strong terms the need for Indonesian history to be written from a nationalist perspective and to help promote national consciousness and unity. The tension between these positions has been an enduring and defining fixture of the development of Indonesian historiography (Curaming, 2002).

Kutipan itu dengan jelas memperlihatkan Yamin yang pada waktu itu menjadi Menteri Pendidikan berpandangan bahwa sejarah memiliki tanggungjawab untuk menanamkan kesadaran nasional dan persatuan. Melalui sejarah nasional yang dibangun, diharapkan generasi muda memiliki semangat nasionalisme yang kuat dalam membangun masa depan Indonesia. 
Permasalahannya adalah bagaimana mata pelajaran sejarah menunaikan tanggungjawabnya, sehingga generasi muda tumbuh menjadi warga bangsa yang memiliki identitas nasional kuat? Salah satu jalan yang ditempuh adalah dengan menyusun bu$\mathrm{ku}$ teks pelajaran sejarah atau dikenal juga sebagai historiografi pendidikan. Melalui uraian, gambar dan tugas terstruktur yang disusun, diharapkan para siswa sebagai audience historiografi pendidikan, mampu mengembangkan identitasnya sebagai bagian dari warga bangsa.

Pertanyaan yang kemudian muncul adalah historiografi pendidikan seperti apakah yang mampu menanamkan identitas nasional dalam diri para siswa dengan efektif? Artikel ini mencoba untuk menelisik historiografi pendidikan di tiga negara, yaitu Amerika Serikat, Australia dan Indonesia. Amerika Serikat dan Australia dipilih karena termasuk negara maju dan generasi mudanya memiliki identitas nasional yang relatih kuat. Indonesia dipilih karena sebagai negara sendiri, sehingga dapat menjadi bahan refleksi kritis akan kekuatan dan kelemahan yang dimiliki oleh historiografi pendidikannya. Agar lebih fokus, permasalahan yang diajukan dalam artikel ini adalah: (1) Bagaimana pendekatan dan wacana yang diproduksi oleh historiografi pendidikan di Amerika Serikat, Australia dan Indonesia; (2) Kesamaan dan perbedaan apa saja yang terdapat pada historiografi pendidikan di Amerika Serikat, Australia, dan Indonesia.

Penelusuran teoretis menunjukkan bahwa buku teks memiliki peran yang sangat penting dalam proses pendidikan. Hasan dan Babaii (2002: 2) menjelaskan bahwa buku teks merupakan kerangka kerja yang mengatur dan menjadwalkan waktu kegiatan program pengajaran. Dari sudut pandang ini, dengan membaca buku teks, siswa mampu mengatur diri untuk menyiapkan pelajaran yang akan dijalani di kelas. Dengan kata lain, melalui buku teks, siswa mampu mengikuti kegiatan belajar mengajar di sekolah dengan lebih baik. Kedudukannya yang penting pada proses pembelajaran menjadikan pemerintah memberi perhatian besar terhadap produksi dan distribusi buku teks. Di Indonesia, pada tahun 2005 Departemen Pendidikan Nasional mengeluarkan Peraturan Menteri Pendidikan Nasional (Permendiknas) No. 11 Tahun 2005 tentang Buku Teks Pelajaran. Pada pasal 3 ayat 1 Permendiknas tersebut diatur bahwa buku teks pelajaran untuk setiap mata pelajaran yang digunakan pada satuan pendidikan dasar dan menengah dipilih dari buku-buku teks pelajaran yang telah ditetapkan oleh Menteri berdasarkan rekomendasi penilaian kelayakan dari Badan Standar Nasional Pendidikan (BSNP).

Kontrol pemerintah terhadap industri buku teks di satu sisi berfungsi sebagai filter ideologis, seperti disinyalir Apple (2000: 43-44) bahwa kontrol terhadap pendidikan merupakan "form of social control, or, perhaps, as the embodiment of cultural dangers". Di sisi lain, kontrol juga dipandang penting untuk menjaga dan mengembangkan kualitas. Dari sudut pandang ini, buku teks pelajaran sejarah atau historiografi pendidikan dipandang berkualitas apabila mampu melahirkan manusia yang memiliki rasa kebangsaan dan cinta tanah air (Depdiknas, 2006: 523).

\section{HISTORIOGRAFI PENDIDIKAN DI AMERIKA SERIKAT}

Secara garis besar, buku-buku teks pelajaran sejarah yang diterbitkan setelah 1996 menggunakan standar nasional sebagai pertimbangan. Ditinjau 
Kajian Perbandingan Historiografi ... - H. Purwanta

dari pendekatan yang digunakan, pengarang memilih pendekatan naratif modern, yaitu menggambarkan terjadinya fenomena sejarah dengan tetap mengkaji sebab-sebabnya. Model penulisannya dapat dikategorikan sebagai berbasis pada urutan kejadian. Hal itu antara lain tampak dari buku Gerald A. Danzer, dkk. yang berjudul The Americans. Isi buku tersebut disusun secara kronologis, baik pada tingkat unit maupun sub unit (bab), sehingga memberi kemudahan bagi siswa untuk mengenali tahap-tahap perkembangan. Apalagi, tema setiap unit dijabarkan ke dalam sejumlah topik bab dan masing-masing topik bab dijabarkan lebih lanjut ke dalam sejumlah pokok bahasan yang spesifik.

Penggunaan pendekatan naratif modern terlihat antara lain pada The Americans bab 2 yang diberi judul The American Colonies Emerge. Pengarang antara lain menggambarkan pembangunan koloni pertama di Jamestown sebagai berikut.

England's first significant attempt to carve out of a colony of its own in North America (after an earlier failed attempt at Roanoke) nearly collapsed, as disease and starvation threatened the new settlement. However, through the determination of its colonists and the development of a marketable crop, England's first permanent settlement in North America took shape...

John Smith sensed trouble from the beginning. Nearly all of the settlers seemed to be consumed by one thoughtthe discovery of gold. Because the investors in the colony demanded a quick return on their investment, the colonists directed much of their energy toward searching the land for riches. As Smith later put it, "There was no talk, no hope, no work, but dig gold, wash gold, refine gold, load gold." Smith warned of disaster, but few listened to. the arrogant captain, who had made few friends on the voyage over...
By the winter of 1607 only 38 colonists remained alive. Standing among them was John Smith, who took control of the settlement. "You see that power now rests wholly with me," he announced. "You must now obey this law, ... he that will not work shall not eat." Smith held the colony together by forcing the colonists to farm. He also received food and support from the nearby Powhatan peoples, who had watched warily as the English established their settlement. Smith, a seasoned soldier, knew the Powhatan easily could wipe out the settlement. So he flattered and negotiated his way into winning an uneasy friendship with the group's leader, Chief Powhatan.

Just as Jamestown began to look like a real village, tragedy struck. A stray spark ignited a gunpowder bag Smith was wearing and set him on fire. Badly burned, Smith headed back to England, leaving Jamestown to fend for itself (Danzer et all, 2002: 44-45)

Pada kutipan di atas dengan sangat jelas pengarang menguraikan secara kronologis fenomena historis pemukiman pertama orang Inggris di Amerika Utara. Digambarkan bahwa setelah mengalami kegagalan pada pembangunan koloni di Roanoke, di bawah perusahaan Virginia Company, dibangunlah koloni pertama Inggris di Amerika Utara, yaitu Jamestown. Sekitar 150 orang pekerja yang didatangkan untuk menjadi pemukim pertama pada bulan April 1607, tinggal 38 orang pada musim dingin tahun yang sama, karena kelaparan dan sakit. Pada situasi sulit itu, John Smith maju menjadi pemimpin dan mengumumkan peraturan bahwa mereka yang tidak bekerja, tidak boleh makan. Pada alinea terakhir pengarang menjelaskan kecelakaan yang dialami oleh John Smith. Dijelaskan bahwa karena luka bakar yang hebat, dia kembali ke Inggris, meninggalkan koloni Jamestown untuk menjaga diri mereka sendiri.

Pendekatan naratif modern juga 
digunakan pada buku terbitan McDougal Littell yang lain, yaitu World History. Pada bab 33: Restruckturing the Postwar World, sub bab 4: The Cold War Divides the World, pengarang antara lain menguraikan konfrontasi yang terjadi di Amerika Latin sebagai berikut.

Fidel Castro and the Cuban Revolution In the 1950s. Cuba was ruled by an unpopular dictator, Fulgencio Batista, who had U.S. support. Cuban resentment led to a popular revolution, which overthrew Batista in January 1959. A young lawyer named Fidel Castro led that revolution. At first, many people praised Castro for bringing social reforms to Cuba and improving the economy. Yet Castro was a harsh dictator. He suspended elections, jailed or executed his opponents, and tightly controlled the press.

When Castro nationalized the $\mathrm{Cu}$ ban economy, he took over U.S.-owned sugar mills and refineries. In response, Eisenhower ordered an embargo on all trade with Cuba. Castro then turned to the Soviets for economic and military aid. In 1960, the CIA began to train anti-Castro Cuban exiles. In April 1961, they invaded Cuba, landing at the Bay of Pigs. However, the United States did not provide the hoped for air support. Castro's forces easily defeated the invaders, humiliating the United States (Beck, et all, 2005: 984-985).

Dari kutipan di atas terlihat bahwa Fulgencio Batista, penguasa yang didukung oleh Amerika Serikat, diturunkan melalui revolusi di bawah pimpinan Fidel Castro. Pada masa pemerintahannya, Fidel Castro melakukan kebijakan nasionalisasi perusahaan asing. Hal itu merugikan kepentingan Amerika Serikat karena sebagian besar perusahaan asing yang beroperasi di Cuba adalah milik pengusaha Amerika Serikat. Presiden Amerika Serikat, Eisenhower, kemudian memerintahkan untuk melakukan embargo perdagangan terhadap Cuba yang mengakibatkan Castro beralih bersahabat dengan Soviet untuk memperoleh dukungan ekonomi dan militer. Pada tahun 1960 Amerika Serikat melatih kelompok anti-Castro dan tahun 1961 melakukan invasi melalui Teluk Babi, tetapi gagal.

Ditinjau dari perspektif wacana identitas nasional, buku teks pelajaran sejarah Amerika Serikat sangat kuat menarasikan. Mark Selden (2005) menerangkan bahwa:

Many American textbooks... invoke national pride in the nation's history, reaching an apogee in the treatment of wars, notably the American revolution and World War II. This pride is manifest in such titles as: The American Pageant, Our American Heritage, The Great Republic, The Enduring Vision, and, perhaps the most lyrical, America: The Glorious Republic. While many of the texts manifest great pride in American achievements, particularly democracy, prosperi$t y$, technological prowess, and the rise to world leadership...

Pada kutipan itu Selden menjelaskan bahwa banyak narasi buku teks Amerika yang membangkitkan kebanggan nasional dalam sejarah nasional, mencapai puncaknya ketika membahas perang-perang, terutama pada revolusi Amerika dan Perang Dunia II. Banyak kalimat yang menarasikan tentang kebanggaan terhadap berbagai keberhasilan Amerika, khususnya dalam demokrasi, kesejahteraan, penguasaan teknologi dan berkembangnya kepemimpinan di dunia.

Temuan Selden tidak jauh berbeda dengan pembacaan James W. Loewen. Dia menyatakan bahwa

Many American history textbooks are studied with biographical vignettes of the very famous (Land of Promise devotes a box to each president) and the famous (The Challenge of Freedom provides "Did You Know?" boxes about Elizabeth Black- 
well, the first woman to graduate from medical school in the United States, and Lorraine Hansberry, author of A Raisin in the Sun, among many others). (Loewen, 1995: 9)

Wacana kesuksesan yang dinarasikan dalam buku teks sejarah begitu dalam membekas dalam diri para siswa, bahkan ketika mereka sudah menjadi mahasiswa. Loewen (1995: 11-12) menguraikan:

When I ask my college students to tell me what they recall about President Wilson, they respond with enthusiasm. They say that Wilson led our country reluctantly into World War I and after the war led the struggle nationally and internationally to establish the League of Nations. They associate Wilson with progressive causes like women's suffrage. A handful of students recall the Wilson administration's Palmer Raids against left-wing unions.

\section{HISTORIOGRAFI PENDIDIKAN DI AUSTRALIA}

Kurikulum nasional pelajaran sejarah di Australia secara garis besar dapat dikelompokkan menjadi dua, yaitu pengetahuan dan pemahaman tentang peristiwa sejarah (Historical knowledge and understanding) serta keterampilan sejarah (Historical skills). Pengetahuan dan pemahaman sejarah telah mulai diajarkan mulai di Taman kanak-kanak. Sampai kelas 2, para siswa belajar sejarah dengan mengamati cerita dari keluarga mereka dan pusaka komunitas mereka. Di kelas 3 sampai kelas 6 , fokusnya diperluas dari sejarah lokal ke regional dan nasional. Mereka diajarkan tentang kehidupan di Australia sebelum tahun 1800, pembangunan bangsa Australia dan hubungan Australia dengan berbagai bangsa lainnya. Dua buah studi yang mendalam pada tahun ini akan mengarahkan para siswa untuk mendapatkan pengetahuan dan pemahaman yang lebih mendalam mengenai topik-topik tertentu.

Dari kurikulum yang disusun, wacana yang dikembangkan pelajaran sejarah Australia lebih pada aspek kognitif, yaitu pengetahuan dan pemahaman terhadap peristiwa sejarah serta keterampilan melakukan penelitian sejarah. Selain unik dari perspektif kurikulum, pelajaran sejarah di Australia juga memiliki kekhasan pada aspek buku teksnya. Berbeda dengan negara-negara Barat pada umumnya, Australia mengembangkan buku teks pelajaran sejarah, khususnya untuk Secondary level dengan berbasis kelas. Maksudnya, setiap tingkatan kelas disediakan satu buku teks yang berbeda dengan buku teks untuk tingkatan kelas lainnya.

Ditinjau dari pendekatan yang digunakan dalam menyusun buku teks pelajaran sejarah, secara garis besar para pengarang memilih menggunakan pendekatan naratif modern dengan model penulisan kombinasi antara urutan kejadian dan tema. Pola itu antara lain tampak pada buku teks karangan Robert Darlington yang berjudul History Alive 10 yang digunakan untuk siswa kelas 10. Fenomena-fenomena historis, baik nasional maupun internasional, yang penting dijadikan judul bab. Untuk membahas setiap tema, setiap bab dibagi ke dalam sub bab, yaitu: pengantar, sub bab 1: sumber sejarah yang dapat digunakan untuk mengkaji tema bab, dan dilanjutkan dengan sub babsub bab berikutnya yang membahas sub tema secara kronologis.

Uraian dengan menggunakan pendekatan naratif terlihat jelas ketika melakukan pembahasan pada sub bab. Pada sub bab 1.2. yang diberi judul The peace treaties and the League of Nations antara lain dijelaskan sebagai berikut. 
On 11 November 1918 the German government accepted an armistice, which ended all fighting in World War I. German troops were exhausted and their morale was broken. The army had run out of reserves, many German people were starving and food supplies were low. The Allies had won the war but they now had the task of creating peace. Would they make treaties that took revenge for Allied losses and suffering or would they seek a peace that would last?

\section{The terrible cost of war}

Five million Allied troops had died to achieve victory in World War I. Another 13 million had been wounded, many of them permanently disabled. The cost in money was also enormous, and France had suffered the destruction of farmland and entire towns and villages. Germany and the other Central Powers had also suffered terribly. They had lost 3.5 million troops and another 8 million were wounded. However, as many people on the Allied side saw it, the Central Powers, especially Germany, had caused the war and should be made to pay (Darlington dkk, 2012: 6).

Dari kutipan di atas tampak bahwa pengarang mengarahkan para pembacanya terbatas hanya pada level mengetahui peristiwa sejarah. Setiap topik atau sub topik hanya diberi uraian dalam satu atau dua alinea pendek. Misalnya pada topik "Mahalnya harga perang", pengarang hanya menguraikan bahwa lima juta orang tentara meninggal sebagai korban Perang Dunia I. Tigabelas juta lainnya mengalami luka dan sebagian dari mereka cacat permanen. Ditinjau dari biayanya juga sangat besar. Perancis menderita karena hancurnya perkebunan, kota-kota dan pedesaan. Sebaliknya Jerman dan anggota Central Power lainnya juga tidak kalah menderita. Mereka kehilangan 3,5 juta orang pasukan dan 8 juta lainnya mengalami luka. Meskipun demikian, hampir semua anggota Sekutu memandang Jerman sebagai penyebab perang, sehingga harus membayarnya.

Pada topik The Treaty of Versailles, sub topik Economic terms, pengarang hanya menjelaskan bahwa daerah Saar di Jerman yang kaya akan batu bara dikuasai Perancis selama 15 tahun. Barang-barang stok kereta api Jerman semuanya disita dan ditambah Jerman harus membangun jutaan tonase kapal untuk Sekutu. Selain itu hampir seluruh batu bara, baja dan berbagai bahan baku yang dimiliki Jerman semuanya harus diserahkan ke Sekutu. Jerman juga wajib untuk membayar kerugian perang terhadap kerusakan yang dialami masyarakat sipil di semua negara anggota Sekutu. Menurut pasal 231, Jerman harus menerima sebagai pihak yang salah, yaitu penyebab perang (Darlington dkk, 2012: 7).

Meskipun uraian hanya berupa narasi singkat, bukan berarti siswa di Australia hanya dituntut untuk mencapai level kognisi terendah, yaitu mengetahui. Sebaliknya, mereka dituntut untuk mencapai level kognisi tertinggi, yaitu evaluasi. Pengembangan kognisi level tinggi itu terutama dilakukan dengan menggunakan tugas terstruktur. Ada 5 macam tugas terstruktur yang dikembangkan, yaitu (1) chronological, term and concepts, (2) explanation and communication, (3) analysis and use of source, (4) historical questions and research, (5) perspectives and interpretations.

Ditinjau dari wacana yang dikembangkan, buku teks pelajaran sejarah di Australia menarasikan bahwa terjadi perkembangan pemikiran dari "negara kulit putih" menjadi negara multikultural. Salah satu fenomena yang digunakan untuk menggambarkan perubahan itu adalah peraturan imigrasi. Pandangan tentang Australia negara kulit putih dijelaskan melalui kebijakan imigrasi sebagai berikut.

In the mid nineteenth century, immigrants from Asia and the Pacific Islands 
had been expelled from Australia in response to white Australians' fear that industrious immigrants would take their jobs by accepting a lower standard of living and working for less money. These actions were reinforced by the immigration Restriction Act 1901, which gave immigration officers greater discretion when deciding whether or not to allow a person entry into the country. One means by which this was done was the dictation test. The dictation test was designed to test that a potential immigrant was literate. The examiner could ensure that the candidate would fail by testing the immigrant in a language with which he or she was unfamiliar (Darlington dkk, 2012: 238).

Dari kutipan di atas dijelaskan dalam buku teks pelajaran sejarah bahwa imigran dari Asia dan kepulauan Pasifik diusir dari Australian. Bagi calon imigran, menurut Undang-Undang Pembatasan tahun 1901, harus menjalani test yang soalnya menggunakan bahasa Inggris. Dari perspektif ini, hanya masyarakat yang berbahasa ibu bahasa Inggris diperbolehkan menjadi warga Australia.

Perubahan besar-besaran terjadi ketika perang Vietnam berlangsung.

As a participant in the Vietnam War and signatory to the United Nations 1951 Convention Relating to the Status of Refugees, Australia had both a moral and legal obligation to accept refugees from Indochina. In 1977, in response to the growing number of refugees throughout Indochina, Australia developed its own refugee policy in which it formally acknowledged its responsibility to resettle a fair proportion of the world's refugees (Darlington dkk, 2012: 250)

Dari kutipan di atas, ditekankan bahwa perubahan kebijakan imigrasi Australia disebabkan oleh pertimbangan moral dan legal sebagai pihak yang menjadi sekutu Amerika Serikat dan terlibat langsung pada perang Vi- etnam. Meski demikian, bukan berarti kebijakan itu berjalan dengan mulus. Sentimen kulit putih tetap muncul, meski tidak berkembang menjadi berskala besar.

Perang Vietnam menjadi titik balik kebijakan imigrasi, sehingga Australia berubah dari negara kulit putih menjadi multikultural. Meskipun demikian, secara sosial politik, kebudayaan kulit putih tetap dominan. Masih membutuhkan proses yang panjang untuk dapat menerima etnik kulit berwarna sebagai bagian integral dari Australia. Hal itu tampak sekali dari pesan yang disampaikan di bawah ini.

Within multicultural Australian society, immigrants were still required to respect Australia's laws and become part of the Australian community, while being encouraged to value and maintain the traditions and customs of their countries of origin. Laws such as the Racial Discrimination Act 1975 made it illegal to discriminate against others on the basis of their race, colour, descent, or national or ethnic origin (Darlington dkk, 2012: 252).

Selain berkembang dari negara kulit putih menjadi multikultural, buku teks pelajaran sejarah juga menarasikan wacana tentang perubahan pandangan tentang lingkungan hidup. Pada umumnya penjelasan berbagai perubahan pemikiran yang terjadi menggunakan perspektif elitis, yaitu mengupas kebijakan pemerintah. Berbeda dengan itu, ketika membahas tentang lingkungan hidup, buku teks pelajaran sejarah Australia membahasnya dari perspektif gerakan penyelamatan lingkungan yang dilakukan oleh Lembaga Swadaya Masyarakat (Darlington dkk., 2012: 210). 


\section{HISTORIOGRAFI PENDIDIKAN DI INDONESIA}

Ditinjau dari pendekatan yang dikembangkan, historiografi Indonesia yang diterapkan untuk Kurikulum 2013 menggunakan pendekatan kombinasi, yaitu struktural dan naratif. Pendekatan struktural, dalam konteks ini adalah bahwa eksplanasi fenomena historis ditempatkan dalam struktur yang memayunginya. Paling tidak ada dua masalah yang ditemukan dalam penggunaan pendekatan struktural. Pertama, penulis menampilkan banyak teori dalam buku teks yang ditulisnya, tetapi tidak melakukan pengujian terlebih dahulu. Akibatnya teori yang seharusnya merupakan abstraksi dari fenomena terkaburkan dengan opini spekulatif.

Penggunaan pendekatan struktural antara lain ketika menguraikan keragaman bangsa Indonesia dengan menggunakan ethnolinguistic sebagai ilmu bantu sejarah. Uraian diawali dengan realitas kontemporer, yaitu keragaman etnis di Indonesia dewasa ini. Selanjutnya penulis menjelaskan asal usul bangsa Indonesia, yang terbagi dalam lima kelompok, yaitu Proto Melayu, Deutro Melayu, Melanosoid, Negroid dan Weddoid.

Menurut Sarasin bersaudara, penduduk asli Kepulauan Indonesia adalah ras berkulit gelap dan bertubuh kecil. Mereka mulanya tinggal di Asia bagian tenggara...Penduduk asli itu disebut sebagai suku bangsa Vedda oleh Sarasin. Ras yang masuk dalam kelompok ini adalah suku bangsa Hieng di Kamboja, Miaotse, Yao-Jen di Cina, dan Senoi di Semenanjung Malaya...

Pendatang berikutnya membawa budaya baru yaitu budaya neolitik. Para pendatang baru itu jumlahnya jauh lebih banyak daripada penduduk asli. Mereka datang dalam dua tahap. Mereka itu oleh
Sarasin disebut sebagai Proto Melayu dan Deutro Melayu. Kedatangan mereka terpisah diperkirakan lebih dari 2.000 tahun yang lalu (Kementerian Pendidikan dan Kebudayaan, 2014a: 34-35).

Penggunaan pandangan ahli untuk memayungi fenomena historis juga dilakukan penulis ketika mengawali penjelasan periode Hindu-Budha sebagai berikut.

Terdapat berbagai pendapat mengenai proses masuknya HinduBuddha atau sering disebut Hindunisasi. Sampai saat ini masih ada perbedaan pendapat mengenai cara dan jalur proses masuk dan berkembangnya pengaruh Hindu-Buddha di Kepulauan Indonesia. Beberapa pendapat (teori) tersebut dijelaskan pada uraian berikut:

Pertama, sering disebut dengan teori Ksatria. Dalam kaitan ini R.C. Majundar berpendapat, bahwa munculnya kerajaan atau pengaruh Hindu di Kepulauan Indonesia disebabkan oleh peranan kaum ksatria atau para prajurit India. Para prajurit diduga melarikan diri dari India dan mendirikan kerajaan-kerajaan di Kepulauan Indonesia dan Asia Tenggara pada umumnya...

Kedua, teori Waisya. Teori ini terkait dengan pendapat N.J. Krom yang mengatakan bahwa kelompok yang berperan dalam dalam penyebaran Hindu-Buddha di Asia Tenggara, termasuk Indonesia adalah kaum pedagang...

Ketiga, teori Brahmana. Teori tersebut sesuai dengan pendapat J.C. van Leur bahwa Hindunisasi di Kepulauan Indonesia disebabkan oleh peranan kaum Brahmana...

Keempat, teori yang dinamakan teori Arus Balik. Teori ini lebih menekankan pada peranan bangsa Indonesia sendiri dalam proses penyebaran kebudayaan HinduBuddha di Indonesia... Pandangan ini dapat dikaitkan dengan pandangan F.D.K. Bosch yang menyatakan bah- 
wa proses Indianisasi di Kepulauan Indonesia dilakukan oleh kelompok tertentu, mereka itu terdiri dari kaum terpelajar yang mempunyai semangat untuk menyebarkan agama Buddha. (Kementerian Pendidikan dan Kebudayaan, 2014a: 78-80).

Di pihak lain, pendekatan naratif dalam historiografi pendidikan Indonesia antara lain terlihat ketika penulis menggambarkan proses pendudukan Jepang di Indonesia sebagai berikut.

Sejak pengeboman Pearl Harbour oleh angkatan udara Jepang pada 8 Desember 1941, serangan terus dilancarkan ke angkatan laut Amerika Serikat di Pasifik. Kemenangan pasukan Jepang seolah-olah tak dapat dikendalikan dan pasukan itu berturut-turut menghancurkan basis militer Amerika. Selain itu, serangan Jepang juga diarahkan ke Indonesia. Serangan terhadap Indonesia muncul dari utara dan timur. Serangan terhadap Indonesia tersebut bertujuan untuk mendapatkan cadangan logistik dan bahan industri perang, seperti minyak tanah, timah, dan aluminium. Sebab, persediaan minyak di Indonesia diperkirakan dapat mencukupi kebutuhan Jepang selama Perang Pasifik (Kementerian Pendidikan dan Kebudayaan, 2014a: 6-7).

Ditinjau dari wacana yang dikembangkan, penulis buku teks sejarah Indonesia terlihat berusaha untuk menempatkan bangsa Indonesia sebagai objek sejarah bangsa asing. Hal itu antara lain tampak pada pembahasan nenek moyang bangsa Indonesia yang disebut dalam buku teks sebagai manusia purba (Kementerian Pendidikan dan Kebudayaan, 2014a: 20) seperi pada gambar 1.

Dari uraian di atas tampak bahwa penulis sengaja memberikan informasi tentang berbagai penemu artefak arkeologis dan temuannya, seperti Schemulling yang menemukan fosil vertebrata, dan Koeningswald dengan fosil Homo

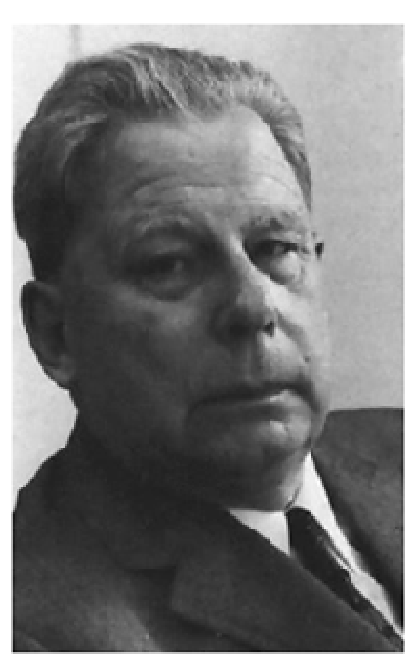

Sumber, Philip V Tobias, Palantologische Zeitschrift, December 1983, Volume 57. Gambar 1.6 Von Koeningswald
Sangiran pertama kali ditemukan oleh P.E.C. Schemulling tahun 1864, dengan laporan penemuan fosil vertebrata dari Kalioso, bagiandari wilayah Sangiran. Semenjak dilaporkan Schemulling situs itu seolah-olah terlupakan dalam waktu yang lama. Eugene Dubois juga pernah datang ke Sangiran, akan tetapi ia kurang tertarik dengan temuan-temuan di wilayah Sangiran. Pada 1934, Gustav Heindrich Ralph von Koeningswald menemukan artefak litik di wilayah Ngebung yang terletak sekitar dua $\mathrm{km}$ di barat laut kubah Sangiran. Artefak litik itulah yang kemudian menjadi temuan penting bagi Situs Sangiran. Semenjak penemuan von Koeningswald, Situs Sangiran menjadi sangat terkenal berkaitan dengan penemuan-penemuan fosil Homo erectus secara sporadis dan berkesinambungan. Homo erectus adalah takson paling penting dalam sejarah manusia, sebelum masuk pada tahapan manusia Homo sapiens, manusia modern.

Gambar 1. Ilustrasi dalam Buku Teks Kurikulum 2013 di Indonesia 
erectus temuannya. Informasi itu menunjukkan bahwa penulis memandang sangat penting bagi para siswa untuk mengetahui aktivitas arkeolog dan hasilnya. Bahkan pandangan itu ditampilkan dengan mengabaikan tuntutan kurikulum 2013, yaitu kompetensi dasar 3.2: "memahami corak kehidupan masyarakat pada zaman praaksara". Penulis dengan antusias menguraikan bahwa bangsa Indonesia merupakan objek kajian para ahli asing. Sampai uraian pada bagian ini berakhir, penulis sama sekali tidak menggambarkan corak kehidupan masyarakat praaksara. Narasi dipenuhi dinamika pemikiran tokoh-tokoh arkeologi dan paleoantropologi, serta pembahasannya tentang temuan fosil di Indonesia. Bahkan pada bagian akhir dikemukakan tentang perdebatan istilah Pithecanthropus erectus atau Homo erectus.

Penempatan bangsa Indonesia sebagai objek juga dapat ditemukan pada uraian tentang awal kebangkitan nasional. Penulis dengan sengaja menempatkan Barat sebagai poros dari dinamika historis yang terjadi di Indonesia. Peran besar Barat pada konteks ini diberikan kepada sebuah program yang bernama Politik Etis. Penempatan politik Etis sebagai determinan bagi tumbuhnya nasionalisme dapat disimak antara lain pada uraian penulis di bawah.

... Adanya Politik Etis membawa pengaruh besar terhadap perubahan arah kebijakan politik negeri Belanda atas negeri jajahan. Pada era itu pula muncul simbol baru yaitu "kemajuan". Dunia mulai bergerak dan berbagai kehidupanpun mulai mengalami perubahan...

...Pengaruh pendidikan Barat itu pula yang kemudian memunculkan sekelompok kecil intelektual bumiputra yang memunculkan kesadaran, bahwa rakyat bumiputra harus mampu bersaing dengan bangsa-bangsa lain untuk mencapai kemajuan... Mereka tidak memandang Jawa, Sunda, Minangkabau, Ambon, atau apa pun karena mereka adalah bumiputra. Pengalaman yang mereka peroleh di sekolah dan dalam kehidupan setelah lulus sangatlah berbeda dengan generasi orang tua mereka. Para kaum muda terpelajar inilah yang kemudian membentuk kesadaran "nasional" sebagai bumiputra di Hindia, dan bergerak bersama "bangsa-bangsa" lain dalam garis waktu yang tidak terhingga menuju modernitas, suatu dunia yang memberi makna baru bagi kaum pelajar terdidik saat itu. (Kementerian Pendidikan dan Kebudayaan, 2014b: 146-147)

\section{KOMPARASI HISTORIOGRAFI DI TIGA NEGARA}

Dari pespektif pendekatan, pengarang buku teks pelajaran sejarah dari ketiga negara memiliki kesamaan, yaitu memilih pendekatan naratif modern. Pendekatan itu dipandang memiliki banyak keunggulan, antara lain fleksibilitas gaya bahasa dengan tetap mentaati berbagai kaidah keilmuan dari sejarah. Dari sudut pandang ini, penggunaan pendekatan naratif menjadikan buku teks dimungkinkan disusun dengan gaya bahasa yang sesuai usia siswa. Melalui gaya bahasa naratif yang sesuai usia audience, siswa mampu lebih mudah memahami berbagai uraian sejarah yang disusun oleh pengarang buku teks. Di pihak lain, pengarang juga lebih mudah menyesuaikan uraian buku teks pelajaran sejarah dengan tujuan kognitif yang telah ditentukan oleh kurikulum. Di Amerika Serikat dan Inggris, tujuan kognitif kurikulum sejarah adalah dari mengetahui, memahami, mengaplikasi, menganalisis sampai mengevaluasi, baik fenomena historis maupun historiografi pendidikannya. Di pihak lain, Australia menetapkan tujuan kognitif 
kurikulum pelajaran sejarah hanya sampai tingkat memahami fenomena historis.

Perbedaan dalam penggunaan pendekatan naratif terletak pada variasi uraian. Pada historiografi pendidikan di Amerika Serikat, uraian diberikan secara mendetail. Sebaliknya, di Australia uraian hanya diberikan sangat singkat, dalam bentuk point-point penting. Pendalaman dilakukan melalui tugas terstruktur yang mencakup pengembangan kognitif dari level rendah sampai tinggi. Di Indonesia, historiografi pendidikan ditampilkan dengan memberi gambaran tentang peristiwa sejarah dengan cukup komprehensif.

Perbedaan lain yang mengemuka adalah bahwa historiografi pendidikan di Indonesia masih menggunakan pendekatan struktural. Pendekatan struktural menuntut penggunaan gaya bahasa ilmiah dan teknis, sehingga sangat sulit dicerna oleh tingkat pemikiran siswa SMA. Selain itu, pendekatan struktural juga menuntut audiece untuk memahami berbagai teori, konsep, generalisasi serta istilah teknis dari ilmu-ilmu sosial dan humaniora. Sebagai contoh, untuk memahami pandangan Sarasin tentang keragaman etnik di Indonesia, siswa dituntut untuk mengerti tentang etnolinguistik dari Antropologi. Tanpa memahami berbagai teori, konsep, dan generalisasi dari ilmu bantu sejarah, siswa hanya akan terjebak pada penghapalan kata per kata dari uraian buku teks pelajaran sejarah.

Apabila diperbandingkan antar dua pendekatan yang digunakan, penerapan naratif modern dalam menyusun historiografi pendidikan lebih mampu menjadi teman dialog bagi siswa. Mengutip pandangan Michelet, Anderson menjelaskan formulasi sebagai berikut.

This formulation is probably unprecedented. Michelet not only claimed to speak on behalf of large numbers of anon- ymous dead people, but insisted, with poignant authority, that he could say what they 'really' meant and 'really' wanted, since they themselves did not understand. From then on, the silence of the dead was no obstacle to the exhumation of their deepest desires. In this vein, more and more 'second-generation' nationalists, in the Americas and elsewhere, learned to speak 'for' dead people with whom it was impossible or undesirable to establish a linguistic connection (Anderson, 1991: 198)

Dari kutipan di atas dapat diambil pemahaman bahwa untuk dapat menanamkan nasionalisme, pendidikan sejarah harus mengungkapkan berbagai hal yang sungguh-sungguh dimaksudkan dan diinginkan oleh para pelaku sejarah di masa lampau, meski mungkin mereka sendiri tak menyadarinya. Dengan demikian terjadi hubungan linguistik (linguistic connection) antara generasi masa lampau dengan generasi sekarang.

Melalui hubungan linguistik tersebut generasi muda menjadi mungkin melakukan dialog reflektif dengan generasi masa lampau dan memahami keinginan dan maksud mereka. Pada tingkat selanjutnya, generasi muda akan dapat menggunakan keinginan dan maksud generasi masa lampau itu untuk diadaptasi dan diterapkan bagi kehidupan sekarang, sehingga antar kedua generasi terdapat kesejajaran atau pararelisme:

This new synchronic novelty could arise historically only when substantial groups of people were in a position to think of themselves as living lives parallel to those of other substantial groups of people - if never meeting, yet certainly proceeding along the same trajectory (Anderson, 1991: 188)

Dari perpektif wacana yang diproduksi, historiografi pendidikan di Amerika Serikat berusaha untuk me- 
nanamkan kepada siswa bahwa mereka adalah bangsa yang besar dan menjadi pemimpin dunia. Hal itu antara lain terlihat dari uraian buku teks pelajaran sejarah yang menekankan pada kesuksesan, pencapaian dan keberhasilan yang diraih oleh berbagai tokoh sejarah Amerika Serikat dalam berbagai peristiwa, baik lokal, nasional maupun internasional. Selain menarasikan keberhasilan, buku teks pelajaran sejarah juga menempatkan bangsa Amerika Serikat sebagai pusat atau pemeran utama. Penempatan sebagai pemeran utama tidak hanya dilakukan dengan memperbanyak penyebutan pelaku sejarah yang berbangsa Amerika Serikat, tetapi menjadikan Amerika Serikat sebagai pembuat sejarah. Dari sudut pandang ini penempatan sebagai pemeran utama tidak hanya orangnya, tetapi juga ideologi dan kepentingannya dalam arti seluas-luasnya dalam usaha mewujudkan tata kehidupan ideal yang dicita-citakan oleh bangsa Amerika Serikat.

Di Australia, historiografi pendidikan berusaha untuk menanamkan kepada siswa bahwa mereka adalah bangsa yang berpemikiran terbuka dan selalu bergerak menjadi masyarakat yang lebih berkualitas. Sebagai contoh, berangkat dari pandangan bahwa Australa merupakan benua kulit putih kemudian sejarah bergerak menjadikan bangsa Australia sebagai masyarakat yang heterogen dan multikultur. Begitu juga terhadap lingkungan hidup. Pemerintah Australia pada awalnya tidak peduli dengan kelestarian hidup kemudian berkembang menjadi sangat mempertimbangkan lingkungan hidup dalam melakukan pembangunan.

Historiografi pendidikan di Indonesia memproduksi wacana yang berkebalikan. Apabila Amerika Serikat ditampilkan sebagai bangsa yang sukses dan mampu memimpin dunia, serta Austra- lia dinarasikan sebagai bangsa yang berpemikiran terbuka dan optimis menuju masa depan yang lebih baik, Indonesia justru ditampilkan sebagai bangsa yang bodoh dan selalu tergantung pada bangsa asing. Dari narasi tentang pra aksara yang dibuat tergantung pada Schemulling, Koeningswald dan kawankawannya, memasuki zaman sejarah diuraikan sebagai masyarakat yang tergantung pada bangsa India dan Arab, sampai zaman modern diuraikan sebagai masyarakat yang tergantung pada kebaikan penjajah Belanda.

Dari perbandingan wacana yang diproduksi, dapat diperkirakan bahwa historiografi pendidikan Indonesia akan memiliki peluang paling besar untuk gagal dalam menanamkan identitas nasional. Generasi muda Indonesia akan mengalami kesulitan paling besar untuk memiliki perasaan bangga terhadap bangsanya. Sebaliknya mereka akan merasa rendah diri dan sangat mudah terjangkit xenosentrisme, yaitu bangga menggunakan produk kebudayaan asing.

\section{SIMPULAN}

Dari perspektif pendekatan, historiografi pendidikan di Indonesia perlu lebih dikembangkan ke arah naratif modern, seperti telah terjadi di Amerika Serikat dan Australia, sehingga siswa sebagai audien mampu lebih mudah memahami fenomena historis yang dibahas secara komprehensif. Gaya bahasa ilmiah dan teknis perlu dikurangi, karena justru lebih banyak menimbulkan kesulitan bagi siswa, dari pada mengembangkan pemikiran kritis mereka. Sebaliknya, historiografi pendidikan Indonesia perlu menggunakan lebih banyak kosa kata dan gaya bahasa yang akrab dalam kehidupan para siswa. 
Untuk mengembangkan kompetensi siswa ke level analisis dan evaluasi, historiografi pendidikan di Indonesia perlu lebih serius memberi perhatian pada tugas terstruktur. Pengembangan tugas terstruktur yang dilakukan oleh historiografi pendidikan di Australia kiranya dapat menjadi contoh menarik. Aspek yang tidak kalah menarik dari historiografi pendidikan di Australia adalah pembelajaran berbasis teknologi informasi. Penyediaan situs yang khusus untuk membantu siswa dalam mengerjakan tugas terstruktur perlu dikembangkan di Indonesia, sehingga indikator-indikator pencapaian kompetensi yang dituntut dapat lebih pasti dan terukur.

Dari perspektif wacana, historiografi pendidikan di Indonesia perlu mengembangkan lebih lanjut Indonesiasentrisme. Selama ini Indonesiasentrisme lebih banyak dipahami sekedar membahas tentang bangsa Indonesia dan fenomena historis yang terjadi di Indonesia. Akan tetapi, narasi yang berkembang menempatkan bangsa Indonesia lebih sebagai objek atau akibat dari kegiatan atau kebijakan bangsa asing. Dengan kata lain, subjek atau pemeran utama dalam sejarah Indonesia ditempati lebih banyak oleh bangsa asing.

Pengembangan Indonesiasentrisme perlu diarahkan pada usaha untuk menempatkan masyarakat Indonesia sebagai subjek atau pemeran utama. Dari sudut pandang ini, kajian sejarah harus menempatkan konstruk mental masyarakat Indonesia sebagai konteks sosial budaya dari suatu fenomena historis. Dengan kata lain, setiap fenomena historis dipahami sebagai usaha masyarakat Indonesia dalam mewujudkan kehidupan ideal yang dicitakan menurut tata nilai dan norma yang mereka hidupi. Langkah itu bukan berarti mengabaikan atau bahkan mene- gasi pengaruh dari bangsa asing, tetapi menempatkannya bukan sebagai faktor utama atau determinan dari tindakan historis bangsa Indonesia.

Melalui penempatan masyarakat Indonesia sebagai subjek atau pemeran utama sejarah, para siswa menjadi lebih mungkin melakukan dialog reflektif dengan tokoh-tokoh sejarah di masa lampau. Para siswa dapat menguji dan mengevaluasi fenomena historis secara lebih objektif dan rasional, karena para tokoh sejarah berkedudukan sebagai manusia yang memiliki pemikiran dan perasaan independen.

\section{DAFTAR PUSTAKA}

Anderson, Benedict. 1991. Imagined Communities: Reflection on the Origin and Spread of Nationalism. New York: Verso.

Ansary, H. and Esmat Babaii. 2002. “Universal Characteristics of EFL/ ESL Textbooks: A Step Towards Systematic Textbook Evaluation". The Internet TESL Journal, Vol. VIII, No. 2, February 2002.

Apple, Michael W. 1993. Official Knowledge: Democratic Education in A Conservative Age. London: Routledge.

Beck, Roger B. et.al. 2005. World History: Pattern of Interaction. Illinois: McDougal Littell.

Curaming, R. 2002. Towards Reinventing Indonesian Nationalist Historiography. Dalam http://kyotoreview.org/issue3-nations-and-stories/an-introduction -to-indonesian-historiography/

Danzer, Gerald A., et.al. 2002. The Americans. Illinois: McDougal Littell

Darlington, Robert. 2012. History Alive 10 for the Australian Curriculum. Queensland: John Wiley \& Sons Australia, Ltd

Depdiknas. 2006. Kurikulum Tingkat Satuan Pendidikan Sejarah. Jakarta: Depdiknas.

Kementerian Pendidikan dan Kebudayaan. 2014a. Sejarah Indonesia Untuk Kelas X Semester 1 dan 2. Jakarta: Kementerian 
Paramita Vol. 25, No. 2 tahun 2015

Pendidikan dan Kebudayaan.

Kementerian Pendidikan dan Kebudayaan. 2014b. Sejarah Indonesia Untuk Kelas XI Semester 1 dan 2. Jakarta: Kementerian Pendidikan dan Kebudayaan.

Kochhar S.K. 2008. Teaching History: Pembelajaran Sejarah. Terjemahan H. Purwanta. Jakarta: Grasindo.

Loewen, W. 1995. Lies My Teacher Told Me: Everything Your American History Textbook Got Wrong. New York: Touchstone Rockeveller Center.

Moreau, Joseph. 2004. School Book Nation: Conflicts over American History Text- books from the Civil War to the Present. Michigan: The University of Michigan Press

National Center for History in The School (NCHS). 1996 National Standards for History. Los Angeles: NCHS.

Peraturan Menteri Pendidikan Nasional Nomor 11 Tahun 2005 tentang Buku Teks Pelajaran.

Selden, Mark. 2005. "Remembering 'The Good War': The Atomic Bombing and the Internment of Japanese-Americans in U.S. History Textbooks". The AsiaPacific Journal. May 8, 2005. 